\title{
Efek Pemberitaan Televisi Tentang Percepatan Penanganan Covid-19 Terhadap Proteksi Kesehatan (Survei Pada Mahasiswa UIN Syarif Hidayatullah Jakarta)
}

\author{
Egih Supendi \\ egih.supendi16@mhs.uinjkt.ac.id \\ Siti Nurbaya \\ siti.nurbaya@uinjkt.ac.id \\ Kholis Ridho \\ kholis.ridho@uinjkt.ac.id
}

\begin{abstract}
Abstrak
Pandemi virus korona telah dijumpai di lebih dari 120 negara dan berita tersebut disiarkan di berbagai media. Penelitian ini bertujuan untuk mengetahui pengaruh pemberitaan tentang virus korona oleh televisi di Indonesia terhadap munculnya kecemasan dan upaya menjaga kesehatan.

Teori yang digunakan dalam penelitian ini adalah teori kultivasi. Teori ini berasumsi televisi secara independen berkontribusi dalam membentuk konsepsi penontonnya dalam menilai realitas sosial.

Metode penelitian yang digunakan survei kuantitatif dengan pendekatan eksplanatif. Populasi penelitian adalah mahasiswa Fakultas Dakwah dan Ilmu Komunikasi UIN Jakarta. Sampel penelitian ini diperoleh dengan teknik teknik accidental sampling dan diperoleh sebanyak 98 orang responden. Metode pengumpulan data menggunakan kuesioner. Teknik analisis data yang digunakan terdiri dari korelasi product moment, uji regresi linear sederhana, dan uji determinasi.

Hasil penelitian diketahui bahwa berita virus korona oleh Gugus Tugas Percepatan Penanganan Covid-19 di televisi berpengaruh terhadap persepsi akan pentingnya proteksi kesehatan sebesar 21,2\%. Sedangkan pengaruh berita virus korona terhadap kecemasan sebesar 24,6\%. Dapat disimpulkan selain dampak pemberitaan terhadap kecemasan akibat pemberitaan lebih tinggi daripada proteksi kesehatan, adalah juga medium televisi masih cukup efektif mengubah pemahaman dan perilaku publik.
\end{abstract}

Kata kunci: kultivasi, terpaan media, berita virus korona, kecemasan, persepsi Permalink/DOI: http://doi.org/10.15408/jsj.v3i2.22987

\section{A. Latar Belakang}

Dalam satu dekade terakhir terjadi perubahan signfikan konsumen media di Indonesia. Sebagaimana disebut dalam survei AC Nielsen (2014) mengenai konsumen media dalam kota-kota di Indonesia menunjukkan televisi masih menjadi media utama yang dikonsumsi masyarakat Indonesia (95\%), lalu internet 
$(33 \%)$, radio $(20 \%)$, surat kabar $(12 \%)$, tabloid (6\%), dan majalah (5\%). Bandingkan dengan kondisi saat ini (2021) sebagaimana disebut dalam survei Reuters Institute 2021 bahwasanya sumber berita konsumen media beralih ke media daring sebesar $89 \%$, televisi (58\%) dan cetak termasuk media social $(20 \%)^{2}$. Meskipun mengalami penurunan konsumen media televisi masih cukup diminati masyarakat luas. Terutama dalam hal pemberitaan pandemic covid-19 yang tersentral pada data yang diterbitkan pemerintah melalui Gugus Tugas Penanganan Covid-19 masih tetap menggunakan televisi sebagai medium utama.

Menurut hasil pantauan Nielsen Television Audience Measurement (TAM) maraknya pemberitaan di sejumlah stasiun televisi terkait Covid-19 di sepanjang periode 1-18 maret berkontribusi kepada kenaikan kepemirsaan program berita. Kepemirsaan televisi terhadap program berita naik signifikan $(+25 \%) .^{3}$

Secara akademik telah diakui informasi dalam tayangan atau berita televisi dapat memengaruhi masyarakat, baik sikap, perilaku, dan hal - hal lainnya. Termasuk dalam hal memengaruhi pengetahuan, kecemasan, dan sikap pemirsa terhadap situasi yang ada. Menurut Mahi M. Hikmat dalam bukunya Jurnalistik Literary Journalism mengatakan efek media massa terdiri dari efek kognitif (pengetahuan), efek afektif (emosional), dan efek konatif

\footnotetext{
${ }^{1}$ https://www.nielsen.com/id/en/press-releases/ 2014/nielsen-konsumsi-media-lebih-tinggi-di-luarjawa/ diakses pada 26 Maret 2020

2 https://databoks.katadata.co.id/datapublish/

2021/06/28/masyarakat-indonesia-palingbanyak-akses-berita-dari-media-daring

3 https://www.nielsen.com/id/id/press-releases/ 2020/covid-19-dan-dampaknya-pada-trenkonsumsi-media/ diakses pada 21 April 2020.
}

(perilaku). Seperti yang dikatakan Yuliandri (2000 : 18), salah satu efek dari penerimaan pesan (informasi) adalah perasaan cemas yang berkaitan dengan efek afektif.

Televisi dalam memengaruhi pemirsanya dapat melalui suatu berita. Berita adalah laporan tentang peristiwa atau pendapat yang memiliki nilai penting, menarik dari sebagian khalayak, masih baru dan dipublikasikan secara luas melalui media massa periodik. ${ }^{4}$ Saat ini berita yang resah diperbincangkan media manapun tak terkecuali televisi yaitu tentang virus korona.

Dalam konteks wabah korona, virus ini masih terus menghantui banyak negara di dunia tak terkecuali Indonesia. Dikabarkan kasus positif virus korona pertamanya pada 2 Maret 2020. Menurut Jokowi, dua WNI yaitu seorang ibu (64 tahun) dan putrinya (31 tahun) keduanya diduga tertular virus korona karena kontak dengan warga negara Jepang yang datang ke Indonesia. Warga Jepang itu terdeteksi korona setelah meninggalkan Indonesia dan tiba di Malaysia. ${ }^{5}$ Semenjak saat itu media massa semakin gencar melansir berita terbaru tentang perkembangan virus korona. Hal ini membuat masyarakat panik hingga mengakibatkan fenomena panic buying di berbagai negara, khususnya kebutuhan alat kesehatan seperti masker, cairan antiseptik hingga sembako yang berlebih. ${ }^{6}$

4 Morissan, Jurnalistik Televisi Mutakhir (Bandung: Kencana, 2008), hal 2.

$5 \quad$ https://nasional.kompas.com/read/2020/ 03/03/06314981/fakta-lengkap-kasus-pertamavirus-corona-di-indonesia?page $=$ all diakses pada 4 April 2020.

6 https://www.cnnindonesia.com/ekonomi/ 20200307220329-92-481428/fenomena-panic- 
Media juga memberitakan identitas pasien covid-19 secara lengkap baik nama, gelar, instansi atau alamat. Diantaranya berita Fokus Indosiar misalnya bahwa salah satu mahasiswa Institut Pertanian Bogor positif terinfeksi Covid-19. Menurut Wali Kota Bogor, Bima Arya Sugiarto, mahasiswa IPB yang positif covid-19 tersebut adalah warga Jakarta yang kos di daerah Sempur, Kota Bogor. Mahasiswa itu tertular dari ayahnya yang positif covid19 saat pulang ke Jakarta. Lalu kembali pulang ke Bogor dan sempat berinteraksi dengan lingkungan tempat tinggal dan kampusnya. $^{7}$

Hal serupa dilakukan kompas tv yang menyebutkan bahwa 36 mahasiswa penghuni asrama Sekolah Tinggi Teologi Bethel, Petamburan Jakarta Pusat juga terinfeksi positif Covid-19. Sebelumnya 134 mahasiswa penghuni asrama STTB telah dites korona hasilnya 36 orang dinyatakan positif. Pihak kampus kemudian meminta bantuan pemerintah daerah untuk segera mengevakuasi mahasiswa yang positif untuk mendapat perawatan medis dan dibawa ke Rumah Sakit Darurat Korona Wisma Atlet, sementara sisanya menjalani isolasi mandiri di asrama. ${ }^{8}$

Kasus lainnya adalah terjadi pada mahasiswa UIN Aceh. Dua mahasiswa Universitas Islam Negeri (UIN) Ar-Raniry Banda Aceh asal Malaysia dinyatakan positif Covid-19. Menurut Ketua Tim Gugus Tugas Percepatan Penanganan

buying-dan-kenaikan-tajam-penjualan-ritel diakses 7 Juli 2020.

https://www.vidio.com/watch/1920235mahasiswa-ipb-positif-corona-berasal-dari-luarbogor diakses pada 21 April 2020.
Covid-19 UIN Aceh, Ibnu Sa'dan, dua orang dari nama-nama yang diumumkan oleh pemerintah Malaysia benar mahasiswa Fakultas Dakwah dan Komunikasi UIN Ar-Raniry. Namun belum bisa memastikan mereka terkena virus tersebut sejak di Banda Aceh atau disaat mereka melakukan perjalanan kembali ke negara asal. ${ }^{9}$

Pemberitaan media satu sisi penting untuk menginformasikan ke public tentang bahaya covid-19 dan penyebarannya yang pesat. Tetapi situasi psikologis saat awal pandemi memungkinkan orang-orang menjauhi atau bahkan menutup interaksi social dengan pasien covid-19. Pergerakan pasien dipantau secara ketat untuk meminimalisir penyebaran virus covid- 19 .

Dari pembahasan di atas, peneliti tertarik untuk meneliti efek media massa kepada khalayak. Yakni untuk mengetahui sejauh mana kehadiran suatu media atau proses penyampaian pesan memengaruhi khalayak dalam berpikir, bersikap, dan berperilaku. Selain itu apakah media televisi juga melakukan edukasi tentang pandemic covid-19. Riset ini membatasi pada pengaruh Pemberitaan Virus Korona oleh Gugus Tugas Percepatan Penanganan Covid-19 di Televisi Terhadap Proteksi Kesehatan pada Mahasiswa Fakultas Ilmu Dakwah dan Ilmu Komunikasi UIN Syarif Hidayatullah Jakarta.

Penelitian ini bersifat eksplanatif, yaitu mencari atau menjelaskan pengaruh terpaan media tentang kasus virus korona

8 https://www.kompas.tv/article/76681/positifcorona-36-mahasiswa-stt-bethel-dievakuasi-ke-rswisma-atlet diakses pada 21 April 2020.

https://www.cnnindonesia.com/nasional/20200420 141603-20-495265/mahasiswa-asal-malaysia-diaceh-positif-corona diakses pada 21 April 2020. 
di televisi terhadap proteksi kesehatan dan kecemasan pada mahasiswa UIN Jakarta. Masalah yang diteliti adalah pengaruh terpaan media tentang kasus virus korona

\section{B. Metode Penelitian}

Penelitian ini menggunakan paradigma positivisme. Dimana suatu gejala dapat diklasifikasikan dan bersifat kausal atau sebab akibat. ${ }^{10}$ Dalam konteks ini adalah mengukur pengaruh terpaan pemberitaan terhadap kecemasan dan upaya proteksi diri dari mahasiswa Fakultas Ilmu Dakwah dan Ilmu Komunikasi UIN Jakarta. Pendekatan penelitian yang digunakan adalah metode kuantitatif. Penelitian kuantitatif menurut Sugiyono sebagai berikut:

"Penelitian kuantitatif dapat diartikan sebagai metode penelitian yang berlandaskan pada filsafat positivisme, digunakan untuk meneliti pada populasi atau sampel tertentu, teknik pengambilan sampel pada umumnya dilakukan secara random, pengumpulan data menggunakan instrumen penelitian, analisis data bersifat kuantitatif atau statistik dengan tujuan untuk menguji hipotesis yang telah ditetapkan". ${ }^{11}$

Untuk metode pengumpulan data digunakan metode survei. Menurut Effendi \& Tukiran (2012) penelitian survei merupakan metode penelitian yang mengambil sampel dari salah satu populasi kemudian menggunakan angket sebagai instrumen pengumpulan data. Angket berisi pertanyaan-pertanyaan terstruktur sebagai instrument untuk memperoleh data data dengan cara membagikan lembar yang

10 Sugiyono, Metode Penelitian Kuantitatif, Kualitatif, dan R\&D, (Bandung: Alfabeta, 2016), hal 42.

11 Op Cit. Sugiyono, Metode Penelitian Kuantitatif, Kualitatif dan $R \& D$, hal 13. di televisi terhadap proteksi kesehatan dan kecemasan pada mahasiswa UIN Jakarta. Media komunikasi yang diteliti adalah media televisi swasta dan nasional.

berisi pertanyaan kepada responden, kemudian berharap responden memberikan respon atas pertanyaan yang diberikan.

Populasi adalah wilayah generalisasi yang terdiri atas: objek/subjek yang mempunyai kualitas dan karakteristik tertentu yang ditetapkan oleh peneliti untuk dipelajari dan kemudian ditarik kesimpulannya. ${ }^{12}$ Adapun yang menjadi populasi dalam penelitian ini ialah mahasiswa aktif Fakultas Ilmu Dakwah dan Ilmu Komunikasi UIN Jakarta angkatan 2014-2019 yang pernah atau mengikuti pemberitaan tentang virus korona. Jumlah mahasiswa Fakultas Ilmu Dakwah dan Ilmu Komunikasi UIN Jakarta sebanyak 3586 orang yang tersebar dalam 6 jurusan. ${ }^{13}$

Tabel 1. Jumlah Mahasiswa FDIK UIN Jakarta

\begin{tabular}{|c|c|}
\hline Jurusan & Jumlah \\
\hline Komunikasi Penyiaran Islam & 1467 \\
\hline Jurnalistik & 171 \\
\hline Kesejahteraan Sosial & 557 \\
\hline Manajemen Dakwah & 617 \\
\hline Pengembangan Masyarakat Islam & 292 \\
\hline Bimbingan Penyuluhan Islam & 482 \\
\hline Total & 3586 \\
\hline
\end{tabular}

Sumber: Database Akademik FDIK UIN Jakarta

12 Sugiyono, Metode Penelitian Kuantitatif, Kualitatif, dan R\&D, (Bandung: Alfabeta, 2016), hal 80.

$13 \quad$ https://data.uinjkt.ac.id/akreditasiinstitusi/standar3/student body group.php?page=2 \&jenjang $=1 \&$ ta $=2019 / 2020$ diakses pada 21 April 2020. 
Sampel adalah proses yang meliputi pengambilan sebagian dari populasi, dan melakukan pengamatan pada populasi yang diteliti. Sehubung dengan sampel yang digunakan porsinya cukup mewakili populasi, maka kita dapat menggeneralisasikan dan yakin bahwa

$$
\begin{aligned}
& n=\frac{N}{1+N(e)^{2}} \\
& \text { Keterangan: } \\
& \mathrm{n} \quad: \text { Sample } \\
& \mathrm{N}: \text { Jumlah Populasi } \\
& \mathrm{e} \quad: \text { standar deviasi }(10 \%)
\end{aligned}
$$

generalisasi yang diambil dapat menggambarkan populasi, sehingga penemuan dan kesimpulan yang diperoleh adalah valid. ${ }^{14}$ Sampel diambil dengan menggunakan rumus Slovin sebagai berikut ini :

$$
\begin{gathered}
n=\frac{3586}{1+3420(0,1)^{2}} \\
n=\frac{3586}{1+3586(0,01)} \\
n=\frac{3586}{1+35,8} \\
n=\frac{3586}{36,8}
\end{gathered}
$$

\section{$n=97,44$ dibulatkan menjadi 98}

Dalam penelitian ini teknik sampling yang digunakan adalah teknik accidental sampling. Teknik sampling ini memiliki sifat "kebetulan" dalam menentukan sampel. Maksud dari teknik ini adalah siapa saja yang secara kebetulan bertemu dengan peneliti dapat digunakan sebagai sampel, bila dipandang orang yang kebetulan ditemui itu cocok sebagai sumber data. ${ }^{15}$

Untuk menunjang hasil penelitian, maka penulis melakukan pengumpulan data yang diperlukan melalui kuisoner. Kuesioner merupakan teknik pengumpulan data yang dilakukan dengan cara memberi seperangkat pertanyaan atau pernyataan tertulis kepada responden untuk dijawabnya. ${ }^{16}$ Kuesioner yang dipakai

14 Consuelo G. Sevilla, dkk, Pengantar Metode Penelitian, (Jakarta: UI Press, 1993), hal 160-161.

${ }^{15}$ Sugiyono, Metode Penelitian Kuantitatif, Kualitatif, dan R\&D, (Bandung: Alfabeta, 2016), hal 85. disini adalah model tertutup karena jawaban telah disediakan dan penggukurannya menggunakan skala likert. Skala likert digunakan untuk mengukur sikap, pendapat, dan persepsi seseorang atau sekelompok orang. yang akan diukur dijabarkan menjadi indikator variabel. Kemudian indikator tersebut dijadikan titik tolak untuk menyusun item-item instrumen yang dapat berupa pernyataan atau pertanyaan. Dalam setiap item instrumen yang digunakan skala likert mempunyai gradasi sangat keperluan analisis kuantitatif, maka jawaban ini dapat diberikan skor. ${ }^{17}$

${ }^{16}$ Sugiyono, Metode Penelitian Kuantitatif, Kualitatif, dan R\&D, (Bandung: Alfabeta, 2016), hal 142.

17 Sugiyono, Metode Penelitian Administrasi, (Bandung: Alfabet, 2005), hal. 107.
Dengan skala likert, maka variabel positif sampai sangat negatif untuk 
Validitas menunjukkan sejauh mana ketepatan suatu alat pengukur itu mengukur apa yang ingin diukur. Sekiranya penulis menggunakan kuesioner di dalam pengumpulan data penelitian, maka kuesioner yang disusunnya harus mengukur apa yang ingin diukurnya. ${ }^{18}$ Pertanyaan atau pernyataan yang ada dalam kuesioner dinyatakan valid jika mempunyai nilai $r$ hitung yang lebih besar dari $r$ standar yaitu $0,3 .{ }^{19}$ Pada penelitian ini, uji validitas diperlukan untuk mengetahui apakah terdapat pertanyaan Rumus validitas:

$$
r_{x y}=\frac{N \Sigma x y-(\Sigma x)(\Sigma y)}{\left.\sqrt{\left[N \Sigma x^{2}\right.}-(\Sigma x)^{2}\right] \cdot\left(N \Sigma x y^{2}-\left(\Sigma y^{2}\right)\right.}
$$

keterangan:

rxy: koefisien korelasi butir

$\mathrm{N}$ : jumlah respon uji coba

$\Sigma x$ : jumah skor item yang diperoleh uji coba

$\Sigma y$ : jumlah skor total yang di peroleh responden atau pernyataan pada kuesioner yang harus diganti atau dibuang karena tidak relevan.

Instrumen dianggap valid jika $r$ hitung $>r$ tabel dan dalam penelitian ini, dianggap memenuhi syarat koefisien dengan $\mathrm{n}=30$ dengan nilai taraf signifikan $5 \%$ yaitu 0,361. Pada tahap ini peneliti melakukan uji coba terhadap 30 responden bayangan yaitu responden yang memiliki kriteria yang sama untuk dijadikan sampel. Responden memilih mahasiswa dengan jurusan acak yang berjumlah 30 orang.
Sementara reliabilitas adalah istilah yang dipakai untuk menunjukkan sejauh mana suatu hasil pengukuran relatif konsisten apabila pengukuran diulang dua kali atau lebih. Penelitian ini menggunakan

$$
r_{11}=\frac{n}{n-1}\left[1-\frac{\sum_{i=1}^{n} s_{i}^{2}}{s_{t}^{2}}\right]
$$

Keterangan:

r11 : koefisien reliabilitas

n : jumlah butir soal

$s_{i}^{2} \quad$ : varian skor

$s_{t}^{2} \quad$ : varian skor total

Analisis data merupakan kegiatan setelah data dari seluruh responden atau sumber data lain terkumpul. Teknik

18 Sofian Effendi dan Tukiran, Metode Penelitian Survei, (Jakarta: LP3ES, 2012), hal 124126. teknik alfa cronbach, yaitu jika hasil dari alfa cronbach $>0,60$ maka data disebut reliabel. Uji reliabilitas menggunakan koefisien reliabilitas alfa cronbach yaitu: 
Pada penelitian ini, peneliti menggunakan statistik inferensial. Statistik inferensial adalah teknik statistik yang digunakan untuk menganalisis data sampel dan hasilnya diberlakukan untuk populasi. ${ }^{20}$ Statistik inferensial digunakan untuk riset eksplanatif yang bertujuan menjelaskan hubungan antara dua atau lebih variabel. Statistik inferensial dibedakan antara asosiatif dan komparatif, karena penelitian ini mengukur hubungan antara pengaruh tayangan berita dengan persepsi dan kecemasan, maka peneliti menggunakan analisis hubungan (asosiatif).

Uji regresi linear sederhana digunakan untuk menganalisa hubungan linear antara satu variabel independen dengan satu variabel dependen. ${ }^{21}$ Rumus uji regresi linear sederhana adalah sebagai berikut:

$$
\begin{aligned}
& \text { Keterangan: } \mathrm{Y}=\mathrm{a}+\mathrm{Bx} \\
& \begin{aligned}
& \mathrm{Y} \quad= \text { variabel tidak bebas } \\
& \mathrm{X} \quad= \text { variabel bebas } \\
& \mathrm{a} \quad= \text { nilai konstan } \\
& \mathrm{b} \quad= \text { koefisien regresi, yaitu angka peningkatan atau penurunan } \\
& \text { variabel dependen yang didasarkan pada variabel independen. }
\end{aligned}
\end{aligned}
$$

Uji koefisien determinasi bertujuan untuk mengetahui seberapa besar kemampuan variabel independen menjelaskan variabel dependen. Dalam output SPSS, koefisien determinasi terletak pada model summary dan tertulis $\mathrm{R}$ square. Nilai R square diketahui baik jika diatas 0,5 karena $\mathrm{R}$ square berkisar antara 0-1.

\section{Temuan Hasil Penelitian \\ 1. Profile Responden}

Pada penelitian ini, dari 98 kuesioner yang tersebar peneliti mendapatkan referensi mengenai identitas responden yang peneliti klasifisikan menjadi tiga bagian yaitu

${ }^{20}$ Sugiyono, Metode Penelitian Kuantitatif, Kualitatif, dan R\&D, (Bandung: Alfabeta, 2016), hal 148.
Waktu penelitian ini dilaksanakan pada Agustus 2020 sampai Januari 2021 pada mahasiswa Fakultas Ilmu Dakwah dan Ilmu Komunikasi UIN Syarif Hidayatullah Jakarta. Penelitian ini dilakukan di UIN Syarif Hidayatullah Jakarta, yang beralamat di Jl. Ir. H. Juanda No. 95, Ciputat Timur, Tangerang Selatan, 15412, Telp. (62-21)740152, Fax. (6221)7402982.

identitas berdasarkan jenis kelamin, usia, dan jurusan:

Tabel 2. Data Responden Berdasarkan Jenis Kelamin

\begin{tabular}{|c|c|}
\hline Jenis Kelamin & Jumlah \\
\hline Laki- laki & 31 \\
\hline Perempuan & 67 \\
\hline
\end{tabular}

${ }^{21}$ Duwi Priyatno, 5 Jam Belajar Olahan Data dengan SPSS 17, ( Yogyakarta: CV Andi Offset, 2009), hal. 172 
Berdasarkan tabel 4 diatas terlihat bahwa identitas responden berdasarkan jenis kelamin jumlahnya lebih banyak perempuan dibanding laki-laki. Pada jenis kelamin laki-laki terdapat 31 orang dan perempuan sebanyak 67 orang.

Tabel 3. Data Responden Berdasarkan Usia

\begin{tabular}{|c|c|}
\hline Usia & Jumlah \\
\hline 18 & 7 \\
\hline 19 & 14 \\
\hline 20 & 14 \\
\hline 21 & 25 \\
\hline 22 & 31 \\
\hline 23 & 7 \\
\hline
\end{tabular}

Berdasarkan tabel 5 dapat diketahui bahwa identitas responden yang berusia 18 dan 23 tahun sebanyak 7 orang, usia 19 dan 20 tahun sebanyak 14 orang, usia 21 tahun sebanyak 25 orang dan yang berusia 22 tahun sebanyak 31 orang. Responden yang berusia 22 tahun merupakan khalayak terbanyak dalam mengonsumsi berita tentang virus korona di televisi.

Tabel 4. Data Responden Berdasarkan Jurusan

\begin{tabular}{|l|c|}
\hline \multicolumn{1}{|c|}{ Jurusan } & Jumlah \\
\hline Komunikasi Penyiaran Islam & 30 \\
\hline Jurnalistik & 35 \\
\hline $\begin{array}{l}\text { Pengembangan Masyarakat } \\
\text { Islam }\end{array}$ & 12 \\
\hline Kesejahteraan Sosial & 7 \\
\hline Manajemen Dakwah & 9 \\
\hline Bimbingan Penyuluhan Islam & 5 \\
\hline
\end{tabular}

Berdasarkan tabel 6 diketahui bahwa identitas responden yang menempati posisi terbanyak yaitu dari jurusan jurnalistik sebanyak 35 orang, kemudian Komunikasi Penyiaran Islam 30 orang, Pengembangan Masyarakat Islam 12 orang, Manajemen Dakwah sebanyak 9 orang, Kesejahteraan Sosial 7 orang, dan Bimbingan penyuluhan Islam 5 orang.

Gambar 1. Frekuensi Responden Menonton Televisi
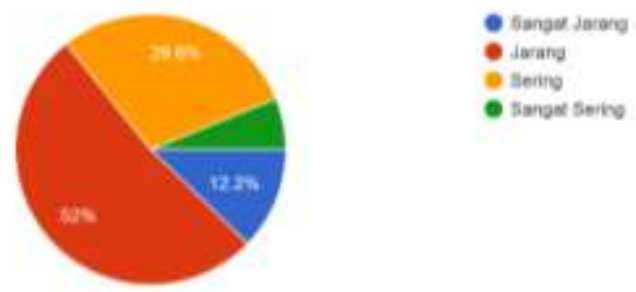

Hasil penyebaran kuesioner terhadap 98 orang menunjukkan bahwa sebanyak $6,2 \%$ dari responden sangat sering menonton tv, $29,6 \%$ dari responden sering menonton tv, 52\% jarang menonton tv, dan $12,2 \%$ dari responden sangat jarang menonton tv.

Gambar 2. Frekuensi Menonton Tayangan Berita Virus Korona oleh Gugus Tugas di Televisi
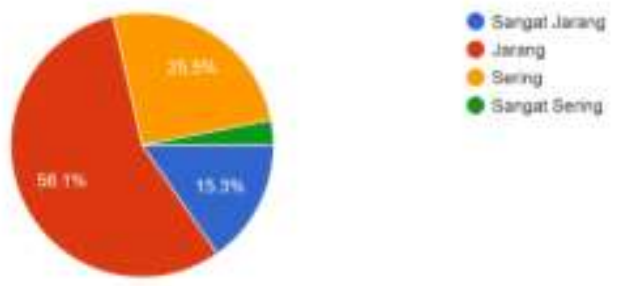

Berdasarkan gambar 3 dapat dilihat bahwa mahasiswa Fidikom UIN Jakarta sebanyak $3,1 \%$ dari responden sangat sering menonton berita virus korona oleh Gugus Tugas di Televisi, 25,5\% sering, $56,1 \%$ jarang, $15,3 \%$ sangat jarang.

Gambar 3. Frekuensi Menonton Tayangan Berita Virus Korona oleh Gugus Tugas di Televisi 2
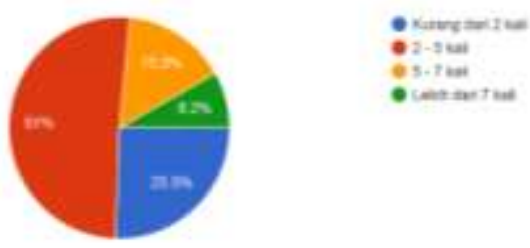
Berdasarkan gambar 4 dapat dilihat bahwa frekuensi menonton tayangan berita virus korona oleh Gugus Tugas di televisi sebanyak $8,2 \%$ responden menonton lebih dari 7 kali selama sebulan, sebanyak $15,3 \%$ responden menonton 5-7 kali, sebanyak 51\% responden menonton 2-5 kali, sebanyak $25,5 \%$ responden menonton kurang dari 2 kali.

Gambar 4. Durasi Menonton Tayangan Berita Virus Korona oleh Gugus Tugas
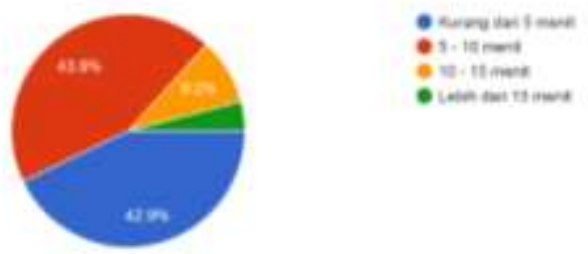

Berdasarkan gambar 5 menujukkan bahwa durasi menonton tayangan berita virus korona sebanyak 4\% menonton lebih dari 15 menit dalam sehari, sebanyak 9,2\% menonton sekitar 10-15 menit, sebanyak 43,9\% menonton sekitar 5-10 menit, dan 42,9\% menonton kurang dari 5 menit.

Gambar 5. Lamanya Mengikuti Tayangan Berita Virus Korona oleh Gugus Tugas di Televisi
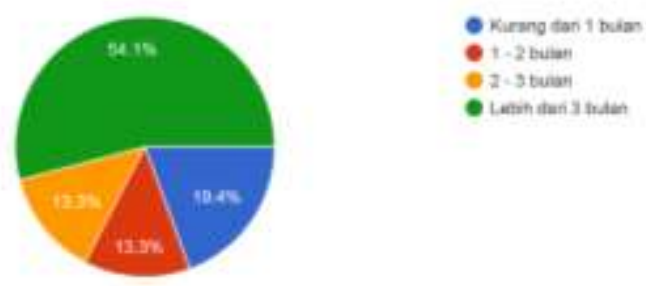

Berdasarkan gambar 6 diatas menunjukkan bahwa lamanya mengikuti tayangan berita virus korona oleh Gugus Tugas di televisi sebanyak 54,1\% lebih dari 3 bulan, sebanyak 26,6\% sekitar 1-3 bulan, dan 19,4\% kurang dari 1 bulan.

\section{Gambar 6. Data Responden Tahu Informasi yang Lengkap dari Televisi}
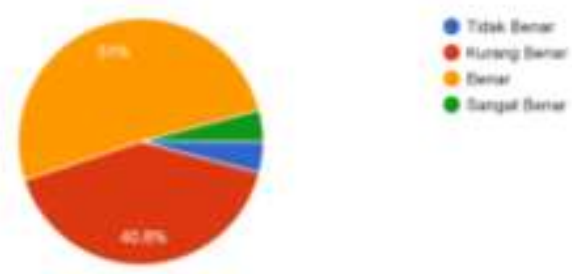

Berdasarkan gambar 7 diatas menunjukkan bahwa sebanyak $4,1 \%$ responden sangat membenarkan bahwa mendapat informasi yang lengkap tentang virus korona dari media televisi, sebanyak $51 \%$ benar, sebanyak $40,8 \%$ kurang benar, dan sebanyak $4,1 \%$ tidak benar. Berdasarkan gambar 8 diatas menunjukkan bahwa sebanyak 26,5\% responden sangat membenarkan bahwa setelah menonton tayangan berita virus korona terhimbau untuk melaksanakan protokol kesehatan, sebanyak 63,3\% benar, sebanyak $8,2 \%$ kurang benar, dan sebanyak $2 \%$ tidak benar.

\section{Gambar 7. Perhatian Responden setelah Menonton} Tayangan Berita Virus Korona
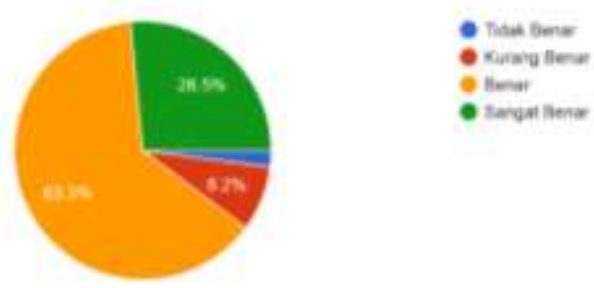


\section{Validitas dan Reabilitas Instrumen}

Validitas merupakan derajat ketepatan antara data yang terjadi pada objek penelitian dengan data yang dapat dilaporkan oleh peneliti. ${ }^{22} \mathrm{Uji}$ validitas digunakan untuk mengetahui apakah butir pertanyaan atau kuesioner dapat

merepresentasikan atau mendefinisikan suatu variabel penelitian. Suatu kuesioner dapat dikatakan valid jika pertanyaan pada kuesioner mampu mengungkapkan sesuatu yang akan diukur oleh kuesioner tersebut. Berikut hasil uji validitas sebagai berikut:

Tabel 5. Hasil Uji Validitas Variabel Terpaan Berita

\begin{tabular}{|l|c|c|l|}
\hline \multicolumn{1}{|c|}{ Pertanyaan } & r-hitung & r-tabel & Hasil \\
\hline $\begin{array}{l}\text { Apakah anda sering menonton tayangan berita di } \\
\text { televisi? }\end{array}$ & 0.579 & 0.360 & Valid \\
\hline $\begin{array}{l}\text { Apakah anda sering menonton berita tentang virus } \\
\text { korona yang ditayangkan oleh Gugus Tugas di } \\
\text { televisi? }\end{array}$ & 0.563 & 0.360 & Valid \\
\hline $\begin{array}{l}\text { Dalam sebulan sebanyak berapa kali anda } \\
\text { menyaksikan berita tentang virus korona yang } \\
\text { ditayangkan oleh Gugus Tugas di televisi? }\end{array}$ & 0.536 & 0.360 & Valid \\
\hline $\begin{array}{l}\text { Berapa lamakah anda dalam sehari menyaksikan } \\
\text { berita tentang virus korona yang ditayangkan oleh } \\
\text { Gugus Tugas di televisi? }\end{array}$ & 0.454 & 0.360 & Valid \\
\hline $\begin{array}{l}\text { Sudah berapa lamakah anda mengikuti berita } \\
\text { tentang virus korona yang ditayangkan oleh Gugus } \\
\text { Tugas di televisi? }\end{array}$ & 0.455 & 0.360 & Valid \\
\hline $\begin{array}{l}\text { Apakah anda mengetahui informasi berita virus } \\
\text { korona secara lengkap dari media televisi? }\end{array}$ & 0.538 & 0.360 & Valid \\
\hline $\begin{array}{l}\text { Setelah menyaksikan berita tentang virus korona, } \\
\text { apakah anda terhimbau untuk melaksanakan } \\
\text { protokol kesehatan? }\end{array}$ & 0.533 & 0.360 & Valid \\
\hline
\end{tabular}

Sumber: Hasil Pengolahan Data, 31 Desember 2019

22 Hardani, dkk, Metode Penelitian Kualitatif dan Kuantitatif, ( Yogyakarta: CV. Pustaka Ilmu, 2020). Hal 212 
Tabel 6. Hasil Uji Validitas Variabel Perspesi

\begin{tabular}{|c|c|c|c|}
\hline Pernyataan & r-hitung & r-tabel & Hasil \\
\hline $\begin{array}{l}\text { Pengetahuan saya terhadap informasi Covid-19 } \\
\text { bertambah }\end{array}$ & 0.439 & 0.360 & Valid \\
\hline $\begin{array}{l}\text { Saya melaksanakan protokol kesehatan } \\
\text { (memakai masker, menjaga jarak, mencuci } \\
\text { tangan) }\end{array}$ & 0.694 & 0.360 & Valid \\
\hline $\begin{array}{l}\text { Saya berusaha menjaga kesehatan tubuh dengan } \\
\text { mengonsumsi makanan yang seimbang }\end{array}$ & 0.456 & 0.360 & Valid \\
\hline $\begin{array}{l}\text { Saya berusaha menjaga kesehatan tubuh dengan } \\
\text { berolahraga rutin setiap hari }\end{array}$ & 0.498 & 0.360 & Valid \\
\hline $\begin{array}{l}\text { Saya berusaha memilih dan menjauhkan diri dari } \\
\text { informasi hoax tentang virus korona }\end{array}$ & 0.424 & 0.360 & Valid \\
\hline $\begin{array}{l}\text { Saya percaya bahwa pandemi Covid-19 akan } \\
\text { segera teratasi }\end{array}$ & 0.588 & 0.360 & Valid \\
\hline $\begin{array}{l}\text { Saya percaya bahwa informasi yang ditayangkan } \\
\text { benar adanya sesuai kenyataan }\end{array}$ & 0.514 & 0.360 & Valid \\
\hline Saya tidak berpergian dan tetap dirumah saja & 0.054 & 0.360 & $\begin{array}{l}\text { Tidak } \\
\text { Valid }\end{array}$ \\
\hline $\begin{array}{l}\text { Saya melakukan segala aktivitas di rumah } \\
\text { (belajar, beribadah) }\end{array}$ & 0.404 & 0.360 & Valid \\
\hline Saya rajin berjemur diri di pagi hari & 0.452 & 0.360 & Valid \\
\hline $\begin{array}{l}\text { Saya tetap menjaga jarak (social \& physical } \\
\text { distancing) }\end{array}$ & 0.557 & 0.360 & Valid \\
\hline $\begin{array}{l}\text { Saya mengetahui perkembangan jumlah korban } \\
\text { Covid-19 setiap harinya }\end{array}$ & 0.249 & 0.360 & $\begin{array}{l}\text { Tidak } \\
\text { Valid }\end{array}$ \\
\hline $\begin{array}{l}\text { Saya tetap melakukan aktivitas di luar rumah } \\
\text { seperti biasanya }\end{array}$ & 0.276 & 0.360 & $\begin{array}{l}\text { Tidak } \\
\text { Valid }\end{array}$ \\
\hline
\end{tabular}




\begin{tabular}{|l|c|c|c|}
\hline $\begin{array}{l}\text { Saya memborong alat kesehatan seperti masker } \\
\text { dan hands-sanitizer }\end{array}$ & 0.448 & 0.360 & Valid \\
\hline $\begin{array}{l}\text { Gugus Tugas memberikan informasi yang } \\
\text { teraktual dan valid }\end{array}$ & 0.580 & 0.360 & Valid \\
\hline
\end{tabular}

Sumber: Hasil Pengolahan Data, 31 Desember 2019

Tabel 7. Hasil Uji Validitas Variabel Kecemasan

\begin{tabular}{|l|c|c|c|}
\hline Pernyataan & r-hitung & r-tabel & Hasil \\
\hline $\begin{array}{l}\text { Sering muncul dalam pikiran saya ingatan yang } \\
\text { mengerikan tentang Covid-19 }\end{array}$ & 0.304 & 0.360 & $\begin{array}{c}\text { Tidak } \\
\text { Valid }\end{array}$ \\
\hline $\begin{array}{l}\text { Saya merasa curiga terhadap setiap orang yang } \\
\text { bergejala (batuk, pilek) kemungkinan menjadi } \\
\text { suspect Covid-19 }\end{array}$ & 0.419 & 0.360 & Valid \\
\hline $\begin{array}{l}\text { Saya merasa khawatir terhadap penyebaran virus } \\
\text { korona tersebut di lingkungan saya }\end{array}$ & 0.616 & 0.360 & Valid \\
\hline $\begin{array}{l}\text { Saya takut berjabat tangan/bersentuhan dengan } \\
\text { orang lain }\end{array}$ & 0.739 & 0.360 & Valid \\
\hline $\begin{array}{l}\text { Saya merasa sangat khawatir/takut tertular atau } \\
\text { menjadi salah satu korban Covid-19 }\end{array}$ & 0.459 & 0.360 & Valid \\
\hline $\begin{array}{l}\text { Saya merasa tidak nyaman/gelisah lingkungan } \\
\text { tempat tinggal saya menjadi daerah pandemi } \\
\text { Covid-19 (zona merah) }\end{array}$ & 0.438 & 0.360 & Valid \\
\hline $\begin{array}{l}\text { Saya merasa gelisah jika saya sedang terkena } \\
\text { penyakit flu/batuk/demam (ciri-ciri orang gejala } \\
\text { Covid-19) }\end{array}$ & 0.574 & 0.360 & Valid \\
\hline $\begin{array}{l}\text { Saya merasa panik dan langsung memeriksakan } \\
\text { ke dokter, apabila sedang terkena penyakit } \\
\text { flu/batuk/demam (ciri-ciri orang gejala Covid-19) }\end{array}$ & 0.433 & 0.360 & Valid \\
\hline $\begin{array}{l}\text { Saya merasa ketakutan jika bertemu dengan } \\
\text { orang yang sedang terkena penyakit } \\
\text { flu/batuk/demam(ciri-ciri orang gejala Covid-19) }\end{array}$ & 0.700 & 0.360 & Valid \\
\hline
\end{tabular}


Saya membayangkan pindah dari lingkungan tempat tinggal saya karena takut tertular Covid19

\subsection{3}

Tidak

Valid
Sumber: Hasil Pengolahan Data, 31 Desember 2019

Berdasarkan data instrumen variabel terpaan pemberitaan terdapat 7 butir pertanyaan, 15 butir pernyataan instrumen variabel persepsi, dan 10 butir pernyataan instrumen variabel kecemasan. Pernyataan atau pertanyaan tersebut dikatakan valid dan tidak valid dilihat dari perbandingan $r$ hitung dengan $r$ tabel yaitu 0,360 dimana peneliti menguji kuesioner terhadap 30 orang secara acak. Jika $r$ hitung sama besar atau lebih besar dari $r$ hitung, butir pertanyaan dapat dinyatakan valid, sedangkan jika $r$ hitung lebih kecil dari $r$ tabel maka butir pertanyaan atau pernyataan dinyatakan tidak valid.

Dari hasil uji validitas didapatkan bahwa 7 butir pertanyaan dari variabel terpaan pemberitaan dinyatakan valid, lalu dari 15 butir pernyataan dari variabel persepsi didapat 12 yang valid dan 3 tidak valid, serta dari 10 butir pernyataan dari variabel kecemasan didapat 8 valid dan 2 tidak valid. Pernyataan yang tidak valid oleh peneliti tidak dipakai pada kuesioner saat pengumpulan data.

\section{Analisis Data}

a) Uji Normalitas KolmogorovSmirnov

Uji normalitas adalah uji yang digunakan untuk mengetahui apakah populasi data berdistribusi normal atau tidak.
Uji reliabilitas adalah uji yang dipakai untuk menunjukkan sejauh mana suatu hasil pengukuran relatif konsisten apabila pengukuran diulang dua kali atau lebih. Pada penelitian ini, alat ukur yang telah di uji reliabilitasnya dengan menggunakan program SPSS 16. Jika hasil dari Cronbach Alpha > 0,60, maka butir pernyataan kuesioner dapat dikatakan reliabel. Berikut ini adalah hasil uji reliabilitas sebagai berikut:

Tabel 8. Hasil Uji Reliabilitas

Reliability Statistics

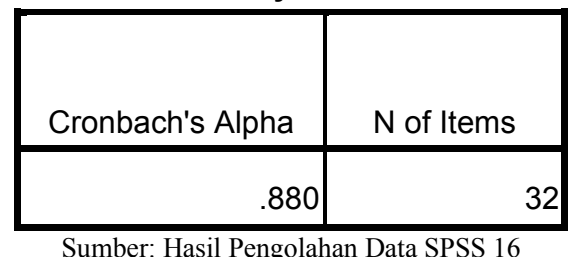

Dari tabel 10 di atas, dapat diketahui bahwa nilai Cronbach Alpha 0,880 yang berarti lebih besar dari 0,60 sehingga kuesioner dapat dikatakan reliabel. 
Tabel 9. Hasil Uji Normalitas Kolmogorov-Smirnov

\begin{tabular}{|l|l|r|}
\hline \multicolumn{2}{|l|}{} & \multicolumn{1}{|c|}{$\begin{array}{c}\text { Unstandardized } \\
\text { Residual }\end{array}$} \\
\hline $\mathrm{N}$ & Mean & 98 \\
\hline $\begin{array}{l}\text { Normal } \\
\text { Parameters }\end{array}$ & d. Deviation & .0000000 \\
\hline $\begin{array}{l}\text { Most Extreme } \\
\text { Differences }\end{array}$ & Absolute & .044 \\
\cline { 2 - 3 } & Positive & .044 \\
\cline { 2 - 3 } & Negative & -.035 \\
\hline Kolmogorov-Smirnov Z & .433 \\
\hline \multicolumn{2}{|l|}{ Asymp. Sig. (2-tailed) } & .992 \\
\hline
\end{tabular}

Sumber: Hasil Pengolahan Data SPSS16

Berdasarkan tabel uji normalitas Kolmogorov-Smirnov dapat diketahui bahwa nilai signifikansi dari uji normalitas adalah 0,992. Nilai tersebut lebih besar dari Cronbach Alpha 0,05 maka dinyatakan terdistribusi normal.

\section{b) Uji Koefisien Korelasi}

Uji koefisien adalah uji yang ditujukan untuk melihat apakah ada hubungan antara variabel bebas ( $\mathrm{X}$ ) dengan variabel terikat ( Y ).

\section{1) Uji Koefisien Korelasi Variabel \\ $\mathrm{X}$ terhadap Variabel $\mathrm{Y}_{1}$}

Pada analisis ini untuk mengetahui pengaruh terpaan berita virus korona oleh Gugus Tugas Penanganan Covid-19 terhadap persepsi mahasiswa. Uji koefisien korelasi dilakukan menggunakan SPSS windows versi 16.0. Berikut adalah rumusan hipotesis yang diujikan sebagai berikut:

H0: tidak terdapat pengaruh antara terpaan pemberitaan tentang virus korona terhadap persepsi mahasiswa akan pentingnya proteksi kesehatan
Ha: terdapat pengaruh antara terpaan pemberitaan tentang virus korona terhadap persepsi mahasiswa akan pentingnya proteksi kesehatan

Tabel 10. Hasil Uji Koefisien Korelasi

\begin{tabular}{|l|l|r|r|}
\hline & \multicolumn{1}{|c|}{$\begin{array}{c}\text { Terpaan } \\
\text { Media }\end{array}$} & \multicolumn{1}{c|}{ Persepsi } \\
\hline \multirow{2}{*}{ Terpaan Media } & $\begin{array}{l}\text { Pearson } \\
\text { Correlation }\end{array}$ & 1 & $.460^{* *}$ \\
\cline { 2 - 4 } & $\begin{array}{l}\text { Sig. (2- } \\
\text { tailed) }\end{array}$ & & .000 \\
\cline { 2 - 4 } & $\mathrm{N}$ & 98 & 98 \\
\hline \multirow{2}{*}{ Persepsi } & $\begin{array}{l}\text { Pearson } \\
\text { Correlation }\end{array}$ & $.460^{* *}$ & 1 \\
\cline { 2 - 4 } & $\begin{array}{l}\text { Sig. (2- } \\
\text { tailed) }\end{array}$ & .000 & \\
\cline { 2 - 5 } & $\mathrm{N}$ & 98 & \\
\hline \multicolumn{3}{|l|}{ Sumber: Hasil Pengolahan Data SPSS16 } \\
\hline
\end{tabular}

Untuk menguji hipotesis diatas dapat dilihat dari hasil teknik analisis Pearson's Correlation ( Product Moment) menggunakan software SPSS 16.0. Jika nilai sig $>0,05$ ( nilai signifikansi lebih besar dari 0,05 ) maka $\mathrm{H} 0$ diterima. Jika nilai sig $<0,05$ (nilai signifikansi lebih kecil dari 0,05) maka $\mathrm{H} 0$ ditolak.

Dari tabel 12 diatas dapat dilihat bahwa nilai signifikansi lebih kecil dari 0,05 yaitu 0,00 yang berarti $\mathrm{H} 0$ ditolak atau terdapat hubungan antara variabel terpaan tayangan berita virus korona terhadap persepsi mahasiswa. Besar hubungan pada hasil uji korelasi Pearson sebesar 0,460 yang berarti hubungan antara terpaan tayangan virus korona terhadap persepsi mahasiswa berada pada level sedang seperti terlihat pada tabel berikut. 


\begin{tabular}{|c|c|}
\hline Interval & Tingkat \\
Koefisien & Hubungan \\
\hline$<0,20$ & Sangat Rendah \\
$0,20-0,39$ & Rendah \\
$0,40-0,70$ & Sedang \\
$0,71-0,90$ & Kuat \\
Lebih dari 0,90 & Sangat Kuat \\
\hline
\end{tabular}

Angka koefisien korelasi pada hasil di atas bernilai positif yaitu 0,460, sehingga hubungan kedua variabel tersebut bersifat searah. Dengan demikian dapat diartikan bahwa semakin tinggi menonton tayangan berita virus korona oleh Gugus Tugas di televisi, maka persepsi mahasiswa akan pentingnya proteksi kesehatan juga akan meningkat.

\section{2) Uji Koefisien Korelasi Variabel}

\section{$\mathrm{X}$ terhadap Variabel $\mathrm{Y}_{2}$}

Berikut adalah rumusan hipotesis yang diujikan sebagai berikut:

H0 : tidak terdapat pengaruh antara terpaan pemberitaan tentang virus korona terhadap persepsi mahasiswa akan pentingnya proteksi kesehatan

$\mathrm{Ha}$ : terdapat pengaruh antara terpaan pemberitaan tentang virus korona terhadap persepsi mahasiswa akan pentingnya proteksi kesehatan.

\begin{tabular}{|l|l|r|r|}
\hline & \multicolumn{1}{|c|}{$\begin{array}{c}\text { Terpaan } \\
\text { Media }\end{array}$} & Kecemasan \\
\hline $\begin{array}{l}\text { Terpaan } \\
\text { Media }\end{array}$ & $\begin{array}{l}\text { Pearson } \\
\text { Correlation }\end{array}$ & 1 & $.496^{* *}$ \\
\cline { 2 - 4 } & $\begin{array}{l}\text { Sig. (2- } \\
\text { tailed) }\end{array}$ & & .000 \\
\cline { 2 - 4 } & $\mathrm{N}$ & 98 & 98 \\
\hline Kecemasan & $\begin{array}{l}\text { Pearson } \\
\text { Correlation }\end{array}$ & $.496^{* *}$ & 1 \\
\cline { 2 - 4 } & $\begin{array}{l}\text { Sig. (2- } \\
\text { tailed) }\end{array}$ & .000 & \\
\cline { 2 - 4 } & $\mathrm{N}$ & 98 & 98 \\
\hline
\end{tabular}

Sumber: Hasil Pengolahan SPSS 16

Dari tabel 14 dapat dilihat bahwa nilai signifikansi lebih kecil dari 0,05 yaitu 0,000 yang berarti $\mathrm{H} 0$ ditolak atau terdapat hubungan antara variabel terpaan tayangan berita virus korona terhadap kecemasan mahasiswa. Besar hubungan pada hasil uji koefisien korelasi Pearson sebesar 0,496 yang berarti hubungan antara terpaan tayangan berita virus korona terhadap kecemasan mahasiswa berada pada level sedang. Angka koefisien bernilai positif yaitu 0,496 , sehingga hubungan kedua variabel tersebut bersifat searah. Dengan demikian diartikan bahwa semakin tinggi menonton tayangan berita virus korona oleh Gugus Tugas, maka tingkat kecemasan mahasiswa juga semakin meningkat.

\section{3) Analisis Regresi Linear \\ Sederhana}

Analisis regresi sederhana digunakan dalam penelitian ini dengan tujuan untuk membuktikan hipotesis mengenai ada atau tidaknya pengaruh variabel pengaruh terpaan tayangan berita virus korona terhadap persepsi dan kecemasan. 
Tabel 13. Hasil Analisis Regresi Linear Sederhana

\begin{tabular}{|c|c|c|c|c|c|c|}
\hline \multirow{2}{*}{\multicolumn{2}{|c|}{ Model }} & \multicolumn{2}{|c|}{ Unstandardized Coefficients } & \multirow{2}{*}{$\begin{array}{c}\begin{array}{c}\text { Standardized } \\
\text { Coefficients }\end{array} \\
\text { Beta }\end{array}$} & \multirow[b]{2}{*}{$\mathrm{T}$} & \multirow[b]{2}{*}{ Sig. } \\
\hline & & B & Std. Error & & & \\
\hline \multirow[t]{2}{*}{1} & (Constant) & 26.961 & 1.683 & & 16.019 & .000 \\
\hline & Terpaan Media & .492 & .097 & .460 & 5.078 & .000 \\
\hline
\end{tabular}

Sumber: Hasil Pengolahan Data Menggunakan SPSS16

maka nilai persepsi bertambah 0,492 .

Berdasarkan tabel, diperoleh nilai signifikansi sebesar $0,000<0,05$, sehingga dapat disimpulkan bahwa variabel pengaruh terpaan tayangan berita berpengaruh terhadap persepsi. Pada nilai konstanta sebesar 26,961 mengandung arti bahwa rata-rata nilai persepsi mahasiswa adalah sebesar 0,492 . Koefisien regresi sebesar 0,492 menyatakan bahwa setiap penambahan $1 \%$ nilai pengaruh tayangan, Koefisien regresi tersebut bernilai positif sehingga dapat dikatakan bahwa arah pengaruh variabel pengaruh tayangan tehadap persepsi adalah positif.

Berdasarkan tabel didapat sebuah persamaan yaitu:

$$
\begin{aligned}
& Y=a+B X \\
& Y=26,961+0,492 X
\end{aligned}
$$

\begin{tabular}{|c|c|c|c|c|c|c|}
\hline & \multirow[b]{2}{*}{ Model } & \multicolumn{2}{|c|}{ Unstandardized Coefficients } & \multirow{2}{*}{$\begin{array}{c}\begin{array}{c}\text { Standardized } \\
\text { Coefficients }\end{array} \\
\text { Beta }\end{array}$} & \multirow[b]{2}{*}{$\mathrm{T}$} & \multirow[b]{2}{*}{ Sig. } \\
\hline & & $\mathrm{B}$ & Std. Error & & & \\
\hline \multirow[t]{2}{*}{1} & (Constant) & 14.066 & 1.602 & & 8.779 & .000 \\
\hline & Terpaan Media & .516 & .092 & .496 & 5.593 & .000 \\
\hline
\end{tabular}

Tabel 14. Hasil Analisis Regresi Linear Sederhana

Sumber: Hasil Pengolahan Data SPSS16

Sama halnya, diperoleh nilai signifikansinya $0,000<0,05$ yang berarti variabel terpaan tayangan berita berpengaruh terhadap tingkat kecemasan. Pada nilai konstanta sebesar 14,066 mengandung arti bahwa rata-rata nilai persepsi mahasiswa adalah sebesar 0,516. Koefisien regresi sebesar 0,516 menyatakan bahwa setiap penambahan $1 \%$ nilai pengaruh tayangan, maka nilai persepsi bertambah 0,516. Koefisien regresi tersebut bernilai positif sehingga dapat dikatakan bahwa arah pengaruh variabel pengaruh tayangan tehadap kecemasan adalah positif. Persamaannya adalah sebagai berikut:

$$
\begin{aligned}
& \mathrm{Y}=\mathrm{a}+\mathrm{BX} \\
& \mathrm{Y}=14,066+0,516 \mathrm{X}
\end{aligned}
$$

Uji koefisien determinasi bertujuan untuk mengetahui seberapa besar kemampuan variabel bebas menjelaskan variabel terikat. 
Tabel 15. Hasil Uji Koefisien Determinasi

\begin{tabular}{|l|r|r|r|r|}
\hline Model & $\mathrm{R}$ & $\mathrm{R}$ Square & \multicolumn{1}{|c|}{$\begin{array}{c}\text { Adjusted R } \\
\text { Square }\end{array}$} & $\begin{array}{c}\text { Std. Error of the } \\
\text { Estimate }\end{array}$ \\
\hline 1 & $.460^{\mathrm{a}}$ & .212 & .204 & 3.683 \\
\hline
\end{tabular}

Sumber: Hasil Pengolahan Data SPSS 16

Berdasarkan output tersebut 21,2\%. Sedangkan sisanya $78,8 \%$ diperoleh koefisien determinasi (R Square) dipengaruhi oleh faktor lain di luar model sebesar 0,212 yang berarti bahwa pengaruh digunakan oleh peneliti. variabel bebas (tayangan berita) terhadap variabel terikat (persepsi) adalah sebesar

Tabel 16. Hasil Uji Koefisien Determinasi

\begin{tabular}{|l|r|r|r|r|}
\hline Model & \multicolumn{1}{|c|}{$\mathrm{R}$} & R Square & \multicolumn{1}{c|}{$\begin{array}{c}\text { Adjusted R } \\
\text { Square }\end{array}$} & $\begin{array}{l}\text { Std. Error of the } \\
\text { Estimate }\end{array}$ \\
\hline 1 & .496 & .246 & .238 & 3.507 \\
\hline
\end{tabular}

Sumber: Hasil Pengolahan Data SPSS 16

Berdasarkan tabel diatas diperoleh koefisien determinasi (R Square) sebesar 0,246 yang berarti bahwa pengaruh variabel bebas (tayangan berita) terhadap

\section{Pembahasan}

Dalam kehidupan masyarakat modern, komunikasi merupakan suatu kebutuhan yang memegang peranan penting terutama dalam proses penyampaian informasi dari satu pihak kepada pihak lain. Kemajuan ilmu pengetahuan dan teknologi telah memudahkan masyarakat dalam menerima informasi-informasi tentang peristiwaperistiwa, pesan, pendapat, berita, dan lain sebagainya. Untuk menyebarkan informasi kepada khalayak yang bersifat massal variabel terikat (kecemasan) adalah sebesar $24,6 \%$. Sedangkan sisanya $75,4 \%$ dipengaruhi oleh faktor lain di luar model yang digunakan oleh peneliti.

diperlukan sebuah media dalam hal ini media massa. Menurut Effendi (1993:24) media massa memiliki kemampuan untuk menimbulkan keserempakan (simultanety) pada pihak khalayak dalam menerima pesan-pesan yang disebarkan.

Komunikasi yang ditujukan kepada sejumlah khalayak yang tersebar, heterogen, dan anonim melalui media sehingga pesan yang sama dapat diterima secara serentak dinamakan komunikasi massa. ${ }^{23}$ Televisi adalah salah satu bentuk media komunikasi massa yang selain
23 Jalaludin, Rakhmat, Psikologi Komunikasi, (Bandung: Pt. Remaja Rosdakarya, 2007), hal. 189. 
mempunyai daya tarik kuat, disebabkan unsur-unsur kata, musik, dan sound effect, juga memiliki keunggulan yaitu unsur visual berupa gambar hidup yang dapat menimbulkan pesan mendalam bagi pemirsanya.

Pesan yang diterima oleh komunikan dapat menimbulkan efek yang disebut efek komunikasi atau efek media massa. Efek ini dapat berupa efek kognitif, yaitu efek yang memberikan perubahan pada apa yang diketahui, dipahami ataupun dipersepsi oleh khalayak. Efek afektif yaitu terjadi apabila komunikasi memberikan perubahan pada apa yang dirasakan, disenangi, ataupun dibenci oleh khalayak. Terakhir efek konatif yaitu pengaruh yang berupa tingkah laku dan tindakan.

Dalam hal penelitian ini, berita atau informasi Gugus Tugas Percepatan Penanganan Covid 19 tentang virus korona yang berasal dari media komunikasi massa yaitu televisi, peneliti meneliti efek media massa yang berupa efek kognitif dan afektif ialah persepsi akan pentingnya proteksi kesehatan dan kecemasan pada mahasiswa UIN Jakarta. Berita terkait covid 19 yang disajikan Gugus Tugas ini mulai disiarkan pada 13 Maret 2020 dan selalu ditayangkan lewat streaming langsung atau breaking news di televisi setiap harinya. Informasi yang ditayangkannya selalu up to date salah satunya tentang himbauan untuk proteksi kesehatan dan informasi korban terdampak positif korona.

Berita tentang virus korona dapat memengaruhi persepsi atau pengetahuan akan pentingnya proteksi kesehatan. Menurut Cohen persepsi didefinisikan sebagai interpretasi terhadap berbagai sensasi sebagai representasi dari objekobjek eksternal, jadi persepsi adalah pengetahuan tentang apa yang ditangkap oleh panca indera. Berdasarkan hasil penghitungan terdapat pengaruh antara variabel terpaan pemberitaan dan persepsi mahasiswa akan pentingnya proteksi kesehatan sebesar 21,2\% dengan besar hubungannya sebesar 0,460 , dimana hal ini menunjukkan tingkat hubungan yang sedang atau cukup.

berdasarkan hasil penelitian, mahasiswa dalam menerima informasi mengenai suatu fenomena sosial atau kenyataan dapat menyeleksi atau memilih informasi apa yang berguna untuknya, selanjutnya mahasiswa akan mengorganisasikan atau upaya menghubungkan informasi yang diterimanya dengan pengetahuan yang ada pada dirinya, dan akan mulai memberikan penafsirannya terhadap informasi yang diterima.

Selain itu, berita tentang virus korona dapat memengaruhi kecemasan mahasiswa. Menurut Namora Lumongga Lubis (2006:14) kecemasan adalah tanggapan dari sebuah ancaman, nyata ataupun khayal karena adanya ketidakpastian di masa mendatang. Kecemasan dialami ketika berpikir tentang sesuatu tidak menyenangkan akan terjadi. Berdasarkan hasil penghitungan bahwa terdapat pengaruh terpaan pemberitaan terhadap kecemasan mahasiswa sebesar $24,6 \%$ dengan besar hubungan sebesar 0,496, dimana hal ini menunjukkan tingkat hubungan yang sedang atau cukup.

Berdasarkan hasil penelitian, kecemasan yang terjadi dapat digolongkan kepada jenis kecemasan yang ringan. Menurut Kartono Kartini (2006:45) kecemasan ringan dapat dibagi menjadi dua yaitu kecemasan ringan yang muncul sebentar adalah kecemasan yang wajar 
terjadi akibat situasi-situasi yang mengancam dan individu tersebut dapat mengatasinya, kecemasan ini membuat individu lebih berhati-hati. Sedangkan kecemasan ringan lama adalah kecemasan yang dapat diatasi tetapi karena individu tersebut tidak segera mengatasi penyebab munculnya kecemasan, maka kecemasan tersebut akan mengendap lama dalam diri individu.

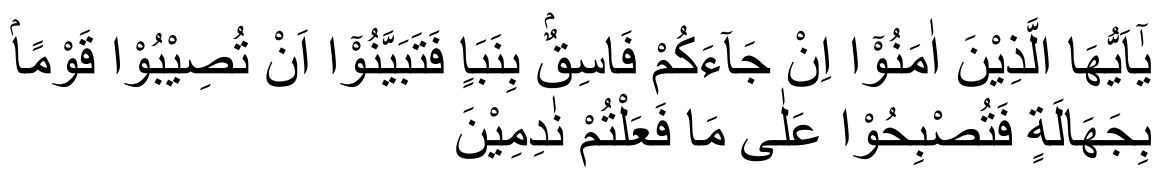

Wahai orang-orang yang beriman! Jika seseorang yang fasik datang kepadamu membawa suatu berita, maka telitilah kebenarannya, agar kamu tidak mencelakakan suatu kaum karena kebodohan (kecerobohan), yang akhirnya kamu menyesali perbuatanmu itu. (QS Al-hujurat :6).

Dalam teori kultivasi menyatakan televisi secara independen akan berkontribusi dalam membentuk konsepsi penontonnya dalam menilai realitas sosial. ${ }^{24}$ Dampak dari menonton tayangan televisi lebih besar berada pada sikap penonton dari pada tataran perilaku. Para pecandu berat televis (heavy viewers) akan mengangap bahwa apa yang terjadi di dunia televisi itulah dunia senyatanya. Jika dihubungkan dengan penelitian ini, maka mahasiswa Fakultas Ilmu Dakwah dan Ilmu Komunikasi yang sering menonton atau menyaksikan program berita tentang virus korona cenderung mempunyai persepsi dan tingkat kecemasan yang tinggi setelah menonton berita tersebut.

${ }^{24}$ Mahi M. Hikmat, Jurnalistik: Literary Journalism, (Jakarta, Prenada Media Group: 2018), hal.46.

\section{Kesimpulan}

Setelah peneliti melakukan survei dan analisis data tentang pengaruh tayangan berita virus korona terhadap persepsi dan kecemasan mahasiswa diperoleh kesimpulan sebagai berikut:

Pertama, berita tentang virus korona yang ditayangkan oleh Gugus Tugas Percepatan Penangangan Covid-19 di televisi berpengaruh secara signifikan terhadap persepsi mahasiswa akan pentingnya proteksi kesehatan yaitu sebesar 21,2 \%. Dengan besar hubungan pada hasil uji korelasi Pearson yaitu 0,460 yang berarti hubungan terpaan berita terhadap persepsi mahasiswa berada pada 
level sedang. Hal ini berarti mahasiswa Fidikom mendapat terpaan berita virus korona di televisi dan mahasiswa yang sering menonton tayangan berita virus korona cenderung lebih meyakini bahwa pentingnya proteksi kesehatan. Hal ini sesuai dengan asumsi teori kultivasi yang menyatakan bahwa semakin sering seseorang meluangkan waktunya untuk menonton televisi maka akan semakin kuat pula kecenderungan orang tersebut untuk menganggap realitas sosialnya sama dengan apa yang sedang ia tonton.

Kedua, berita tentang virus korona yang ditayangkan oleh Gugus Tugas Percepatan Penanganan Covid-19 di Televisi juga berpengaruh terhadap kecemasan mahasiswa yaitu sebesar $24,6 \%$. Dengan besar hubungan pada hasil uji korelasi Pearson yaitu sebesar 0,496, sehingga hubungan ini berada pada level yang sedang.

\section{Daftar Pustaka}

Consuelo G. Sevilla, dkk, Pengantar Metode Penelitian, (Jakarta: UI Press, 1993), hal 160-161.

Duwi Priyatno, 5 Jam Belajar Olahan Data dengan SPSS 17, ( Yogyakarta: CV Andi Offset, 2009), hal. 172

Hardani, dkk, Metode Penelitian Kualitatif dan Kuantitatif, ( Yogyakarta: CV. Pustaka Ilmu, 2020). Hal 212

Jalaludin, Rakhmat, Psikologi Komunikasi, (Bandung: Pt. Remaja Rosdakarya, 2007), hal. 189.

Mahi M. Hikmat, Jurnalistik: Literary Journalism, (Jakarta, Prenada Media Group: 2018), hal.46.

Mohammad Mulyadi, Penelitian Kuantitatif dan Kualitatif, (Jakarta: Publica Institute,2010), hal. 109.
Morissan, Jurnalistik Televisi Mutakhir (Bandung: Kencana, 2008), hal 2.

Sofian Effendi dan Tukiran, Metode Penelitian Survei, (Jakarta: LP3ES, 2012), hal 124-126.

Sugiyono, Metode Penelitian Kuantitatif, Kualitatif, dan $R \& D$, (Bandung: Alfabeta, 2016), hal 42

https://www.nielsen.com/id/en/pressreleases/2016/gen-zkonsumen-potensial-masa-

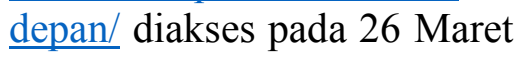
2020

https://www.nielsen.com/id/id/pressreleases/2020/covid-19-dandampaknya-pada-trenkonsumsi-media/ diakses pada 21 April 2020.

https://nasional.kompas.com/read/2020/ 03/03/06314981/faktalengkap-kasus-pertama-virus- 
corona-di-indonesia?page $=$ all diakses pada 4 April 2020.

https://www.cnnindonesia.com/ekonomi /20200307220329-92481428/fenomena-panicbuying-dan-kenaikan-tajampenjualan-ritel diakses 7 Juli 2020.

https://www.vidio.com/watch/1920235mahasiswa-ipb-positifcorona-berasal-dari-luarbogor diakses pada 21 April 2020.

https://www.kompas.tv/article/76681/po sitif-corona-36-mahasiswa- stt-bethel-dievakuasi-ke-rswisma-atlet diakses pada 21 April 2020.

https://www.cnnindonesia.com/nasional /20200420141603-20495265/mahasiswa-asalmalaysia-di-aceh-positifcorona diakses pada 21 April 2020.

https://data.uinjkt.ac.id/akreditasiinstitusi/standar3/student bod y_group.php?page $=2 \&$ jenjan $\mathrm{g}=1 \& \mathrm{ta}=2019 / 2020$ diakses pada 21 April 2020. 